\title{
DOMESTIC TOURISTS NEW DINING BEHAVIOUR IN RELATION TO COVID-19 AT ISLAND SETTING IN TERENGGANU, MALAYSIA
}

\author{
Norsyakira Ahmadi', Mohd Hairi Jalis², Fathilah Ismail ${ }^{3}$, Abdul Wahab Mohamad Rahijan ${ }^{4}$ \\ \& Wan Zainal Shukri Wan Hafiz ${ }^{5}$ \\ 1,2Faculty of Hotel and Tourism Management, University Teknologi MARA (Terengganu) \\ ${ }^{3}$ Faculty of Business, Economics and Social Development, Universiti Malaysia Terengganu \\ 4,5Faculty of Fisheries and Food Science, Universiti Malaysia Terengganu \\ (wanafiz@umt.edu.my)
}

\begin{abstract}
Today, the tourism industry has grown rapidly and many destinations have been recognised as tourist niches in a bid to stay competitive in the industry. Island tourism is one of the most popular tourism niches. Island tourism in Malaysia has lured tourists from all over the world to come to Malaysia, offering tourist a unique and unforgettable tourism experience. It has become one of the most famous types of activities tourists. Moreover, tourists are showing an increasing interest in local foods at the destination and dining has become a special experience while on vacation. Dining itself is a pleasurable sensory experience that is a key part of the holiday experience, which influences a tourists' experience and makes it memorable and this in turn influences the tourist's intention to revisit the destination, especially an island destination. However, the recent COVID-19 pandemic, the subsequent Movement Control Order (MCO) and COVID-19 Standard Operating Procedures (SOP) enforced to control the spread of the pandemic have significantly influenced tourists dining behaviours and perceptions particularly with regard to dine-in options at any food establishment/outlets.
\end{abstract}

KEYWORDS: Tourist dining behaviour, Malaysia's Domestic tourist, Local Island food, Covid-19 Pandemic, Willingness-to-try, Risk perception

\section{PURPOSE AND BACKGROUND}

Dining out when travelling involves uncertainty where their purchase decisions are questionably reliant on pre-judged perceptions especially during the current COVID-19 pandemic. To date, tourists dining behaviour toward unfamiliar local foods especially at island destinations remains unexplored.

This study aims to explore new dining behaviours among local tourists in island settings following the recent COVID-19 pandemic. This study employed qualitative research methods which it used to conduct its research on Redang Island and Perhentian Islands, in Malaysia. The research paper aims to explore the domestic tourist's behaviour towards dining-in at restaurants and the impact on their willingness to consume local foods while travelling on small islands in Malaysia in the wake of the COVID-19 pandemic.

\section{METHODOLOGY}

Using a qualitative approach, a total of sixteen participants of domestic tourists from Redang and Perhentian Island in Terengganu, Malaysia participated in this study. Semi-structured interviews were carried out between July and August 2020 during the Recovery Movement Control Order (RMCO) period, focusing on restaurants on the two Islands. The interviews were audio recorded and transcribed. 
Transcripts were content analysed using ATLAS.TI 9.0, and coded in stages. The data was then analysed using thematic analysis.

\section{FINDINGS}

Based on the completed thematic analysis, the findings of this study show that there are a total of seven factors that affect the dining behaviour of domestic tourists that travel to Redang and Perhentian Island during the COVID-19 pandemic including; emotional connections, the value of money, support for the local economy and tourism industry, risks to safety, acceptance on new norms, neophobia, and the cleanliness and hygiene have emerged as new dining behaviours among the domestic tourists.

\section{CONCLUSION}

In conclusion, most of the domestic tourists that participated in this study showed that they connected emotionally with island by experiencing the local cuisine. This gastronomic venture indirectly supports tourism activities and boosts the income of the local community.

Due to COVID-19 pandemic the tourism industry is facing problems with international tourists' numbers as such it is great that the local authorities are encouraging residents to travel domestically as this will help support the growth of the local economy.

Besides that, risk prevention measures imposed by the local government to reduce the transmission of the COVID-19 pandemic also seemed to make residents realise the importance of good food hygiene, cleanliness, safety, and increase their risk perception.

Thus, it is important for tourism industry representatives and stakeholders to cooperate and educate domestic tourists on local cuisines on offering each state especially that which is unique to the islands under review. This will help them understand and appreciate the uniqueness of the local cuisines on offer on the island.

\section{CONTRIBUTION/PRACTICAL IMPLICATIONS}

The findings help restaurateurs, resort operators, and other tourism stakeholders at islands destination gain a deeper understanding of the changes to the domestic tourists' dining behaviours especially towards food served on the island.

The findings of this study also provide insightful information for tourism marketers and hospitality businesses to develop their gastronomic products and services in the future. The results also show that most tourists learn to love the island environment and have an emotional connection with island through the food that it offers. This could help boost local island tourism and consequently their economy. Amid the COVID-19 pandemic, results show that due to the risks local food premises cleanliness has become a priority in deciding whether to dine-in at restaurants on the islands. The local food risk perception framework in this research paper will help boost domestic tourists' trust and may potentially improve patronage at local businesses, the social well-being of people on the islands, and the image of the country as an island getaway destination. 


\section{REFERENCES}

Birch, D., \& Memery, J. (2020). Tourists, local food and the intention-behaviour gap. Journal of Hospitality and Tourism Management, 43(December 2019), 53-61. https://doi.org/10.1016/j.jhtm.2020.02.006

Cohen, E., \& Avieli, N. (2004). Food in tourism - Attraction and impediment. Annals of Tourism Research, 31(4), 755-778. https://doi.org/10.1016/j.annals.2004.02.003

Gursoy, D., \& Chi, C. G. (2020). Effects of COVID-19 pandemic on hospitality industry: Review of the current situations and a research agenda. Journal of Hospitality Marketing and Management, 29(5), 527-529. https://doi.org/10.1080/19368623.2020.1788231 